\title{
PENGARUH INTELEGENSI QUOTIENT DAN KEMANDIRIAN BELAJAR TERHADAP KEMAMPUAN KOMUNIKASI MATEMATIS PADA MAHASISWA PROGRAM STUDI PENDIDIKAN MATEMATIKA
}

\author{
Sri Dewi ${ }^{1}$ \\ Program Studi Pendidikan Matematika FKIP Universitas Batanghari ${ }^{1}$ \\ e-mail: $\underline{\text { dedewsri1982@gmail.com }}$
}

\begin{abstract}
ABSTRAK
Tujuan dari penelitian ini untuk mengetahui dan menganalisis pengaruh intelegensi quotient dan kemandirian belajar secara parsial terhadap kemampuan komunikasi matematis pada mahasiswa program studi pendidikan matematika, untuk mengetahui dan menganalisis pengaruh intelegensi quotient dan kemandirian belajar secara simultan terhadap kemampuan komunikasi matematis pada mahasiswa program studi pendidikan matematika. Metode yang digunakan adalah metode penelitian kuantitatif dengan jumlah populasi sebanyak 58 mahasiswa. Sehingga sampel penelitian ini adalah populasi itu sendiri. Teknik analisis data yang digunakan adalah analisis regresi linier berganda dengan menggunakan bantuan computer SPSS versi 20. Hasil penelitian ini ditemukan bahwa secara parsial telah diperoleh perhitungan dan pembahasan bahwa variabel intelegensi quotient $\left(\mathrm{X}_{1}\right)$ berpengaruh positif secara signifikan terhadap kemampuan komunikasi matematika (Y) dengan nilai t hitung variabel intelegensi quotient sebesar 2,665 $>\mathrm{t}$ tabel $=1,671$ dan taraf nilai Sig $=0,010<0,05$, sehingga $\mathrm{H}_{0}$ ditolak dan $\mathrm{H}_{1}$ diterima. Sedangkan untuk variabel kemandirian belajar $\left(\mathrm{X}_{2}\right)$ diperoleh perhitungan dan pembahasan bahwa tidak ada pengaruh yang signifikan terhadap kemampuan komunikasi matematika $(\mathrm{Y})$ nilai $\mathrm{t}$ hitung variabel intelegensi quotient sebesar $-0,112<\mathrm{t}$ tabel $=1,671$ dan taraf nilai Sig $=0,890>0,05$, sehingga $\mathrm{H}_{0}$ diterima dan $\mathrm{H}_{1}$ ditolak. Secara simultan intelegensi quotient $\left(\mathrm{X}_{1}\right)$ dan kemandirian belajar $\left(\mathrm{X}_{2}\right)$, beperngaruh signifikan terhadap kemampuan komunikasi matematika $(\mathrm{Y})$ dengan nilai $\mathrm{F}$ hitung sebesar 3,573 > F table sebesar 3,160 dan taraf nilai sig Sig $=0,015<0,05$, sehingga $\mathrm{H}_{0}$ ditolak dan $\mathrm{H}_{1}$ diterima. Kemampuan variabel intelegensi quotient $\left(\mathrm{X}_{1}\right)$ dan kemandirian belajar $\left(\mathrm{X}_{2}\right)$ menerangkan variasi variabel kemampuan komunikasi matematika $(\mathrm{Y})$ sebesar $43 \%$ dan sisanya diperngaruh variabel independen lainnya sebesar $57 \%$.
\end{abstract}

Kata kunci Intelligence Quotient, Kemandirian Belajar, Komunikasi matematis

\begin{abstract}
The purpose of this study was to determine and analyze the effect of intelligence quotient and partial learning independence on the mathematical communication skills of students of the mathematics education study program, to know and analyze the effect of intelligence quotient and independent learning simultaneously on mathematical communication skills in students of mathematics education study program. The method used is quantitative research methods with a population of 58 students. So that the sample of this study is the population itself. The data analysis technique used is multiple linear regression analysis using SPSS version 20 computer assistance. The results of this study found that partially the calculation and discussion has been obtained that the intelligence variable quotient (X1) has a significant positive effect on mathematical communication skills $(Y)$ with a value $t$ count of the quotient intelligence variable is 2,665 $>t$ table $=1,671$ and the Sig $=0.010<0.05$, so that $H 0$ is rejected and $H 1$ is accepted. As for the learning independence variable (X2), the calculation and discussion showed that there was no significant effect on the ability of mathematics communication $(Y)$, the $t$ value of the quotient intelligence variable was $-0.112<t$ table $=1.671$ and the value level was Sig $=0.890>0.05$, so that $\mathrm{HO}$ is accepted and $\mathrm{H} 1$ is rejected. Simultaneously intelligence quotient (X1) and independent learning (X2) have a significant effect on mathematics communication skills $(Y)$ with a calculated $F$ value of 3.573 $>$ F table of 3.160 and the level of sig value Sig $=0.015<0.05$, so that $\mathrm{HO}$ is rejected and $\mathrm{H1}$ accepted. The ability of the quotient intelligence variable (X1) and learning independence $(X 2)$ explains the variation of the variable mathematics communication ability $(Y)$ by $43 \%$ and the rest is influenced by other independent variables by $57 \%$.
\end{abstract}

Keywords : Intelligence Quotient, Independent Learning, Mathematical Communication 


\section{PENDAHULUAN}

Dunia pendidikan menjadi tumpuan untuk meningkatkan kualitas sumber daya manusia. Untuk itu pendidikan tidak dapat dikesampingkan begitu saja dalam perencanaan pembangunan nasional, karena pendidikan merupakan pintu gerbang untuk keluar dari kebodohan yang membuat negara ini tertinggal. Secara substansi salah satu usaha atau kegiatan yang dijalankan dengan sengaja, teratur dan berencana dengan maksud mengubah atau mengembangkan perilaku yang diinginkan adalah melalui pendidikan. Tidak bisa dipungkiri bahwa di Indonesia saat ini pendidikan belum bisa dikatakan belum berhasil atau belum berjalan dan berkembang dengan baik bila dibandingkan dengan pendidikan di negaranegara lainya. Hal ini dikarenakan banyaknya problema yang muncul di dalam dunia pendidikan di negara ini. Salah satu problema yang paling krusial adalah rendahnya kualitas pendidikan. Kualitas pendidikan menentukan tingkat intelegensi seseorang.

Intelegensi adalah salah satu aspek mental yang memiliki fungsi penting didalam aktivitas kehidupan manusia. Hampir pada setiap aktivitasnya, manusia memerlukan kecerdasan, baik dalam menghadapi setiap masalah atau menghadapi tantangan-tantangan kehidupan, maka akan nampak terasa betapa pentingnya peranan intelegensi. Peranan intelegensi dalam menunjang suatu usaha individu besar sekali, sebab intelegensi pada dasarnya adalah kecakapan individu untuk menyusun diri dengan tuntutan lingkungan. Apabila pendidikan bisa menciptakan intelegensi yang tinggi akan memungkinkan suatu negara tersebut mencapai tujuanya. Seperti yang termaktub dalam UUD 1945 salah satunya tujuan negara adalah mencerdaskan kehidupan bangsa. Untuk mencapai tujuan itu, salah satunya adalah melalui pendidikan untuk menciptakan manusia yang memiliki kecerdasan atau intelegensi yang tinggi.
Intelegensi dan keberhasilan dalam pendidikan adalah dua hal yang saling berkaitan. Hal tersebut diperkuat oleh pendapat Syah (2013) “Tingkat kecerdasan atau intelegensi (IQ) peserta didik tak dapat diragukan lagi, sangat menentukan tingkat belajar peserta didik. Dimana biasanya individu yang memiliki intelegensi yang tinggi dia akan memiliki prestasi yang membanggakan di kelasnya, dan dengan prestasi yang dimiliki dia akan lebih mudah meraih keberhasilan.

Keberhasilan prestasi akan mudah diraih apabila para peserta didik memilki sifat kemandirian dalam belajar. Kemandirian belajar yang dimiliki seorang peserta didik, mendorong peserta didik tersebut untuk dapat berperilaku tidak bergantung kepada orang lain. Penyebab kualitas pendidikan rendah dapat terjadi karena kurangnya kemandirian belajar yang didorong oleh gairah dan semangat yang seharusnya ada dalam diri pribadi seseorang. Kemandirian belajar salah satu faktor yang bisa meningkatkan mutu pendidikan. Oleh sebab itu, kemandirian belajar perlu dibina sejak peserta didik masih dalam pendidikan usia dini, sehingga apabila peserta didik sudah memasuki dunia pendidikan perguruan tinggi mereka sudah terbiasa untuk melakukan kemandirian dalam belajar. Hal ini pula diperlukan peranan orang tua dalam mendidik anak-anak terbiasa belajar mandiri di rumah. Tidak hanya orang tua saja, semua pihak yang terkait dalam meningkatkan kualitas pendidikan perlu memperhatikan kebiasan dari kemandirian dalam belajar.

Untuk melihat kualitas dari mutu pendidikan salah satunya bisa dilihat dari para peserta didik mampu berkomunikasi dengan baik. Komunikasi bisa dilihat dalam bentuk lisan dan tulisan dalam mengungkapkan dan menyampaikan gagasan atau ide-ide terhadap proses pembelajaran. Menurut Bungin (2007) Komunikasi adalah sebuah proses memaknai 


\section{$\pi$ (Phi)}

yang dilakukan oleh seseorang terhadap informasi, sikap, dan perilaku orang lain yang berbentuk pengetahuan, pembicaraan, gerak-gerik, atau sikap, perilaku dan perasaan-perasaan, sehingga seseorang membuat reaksi-reaksi terhadap informasi, sikap, dan perilaku tersebut berdasarkan pada pengalaman yang pernah dia alami.

Salah satu kemampuan yang perlu dimiliki peserta didik dalam matematika adalah kemampuan komunikasi matematis. Menurut NCTM (2000), komunikasi matematis adalah cara peserta didik untuk berbagi ide matematika yang telah dipelajari dan diklarifikasi dalam pemahaman. Kosko and Wilkins (2010) mengungkapkan kemampuan komunikasi matematis yaitu "Students who write to explain or describe solution strategies experience an improvement in their problem solving skills”. Melalui komunikasi, ide-ide menjadi objek refleksi, dapat diperbaiki, didiskusikan, dan dirubah. Ketika peserta didik ditantang untuk mengkomunikasikan hasil pemikiran mereka kepada orang lain secara lisan atau tertulis, mereka belajar menjelaskan, menyakinkan, dan menggunakan bahasa matematika dengan tepat.

Kemampuan komunikasi matematis perlu dimilki dalam pembelajaran matematika, karena hal kemam communication. You have to be able to communicate the concepts. You have to be able to communicate your thinking. Numbers are not enough for any good mathematician. You have to prove. You have to convince". Untuk memilki kemampuan komunikasi matematika diperlukan suatu latihan secara kontinu melalui belajar mandiri. Seperti yang diungkapkan Prayuda, Thomas, dan Basri (2014) kemandirian belajar dalam penelitian ini adalah suatu sikap yang didorong oleh keinginan, inisiatif, dan tanggung jawab sendiri untuk menentukan serta mencari sumber belajar dan metode pembelajaran tanpa suruhan atau dorongan orang lain. Dengan belajar mandiri melatih diri pribadi memilki komunikasi matematis yang baik, apabila peserta didik memilki komunikasi matematis yang baik bisa dikatakan peserta didik tersebut menunjukan intelegensi yang baik pula, sehingga mutu pendidikan bisa dikatakan berhasil tercapai.

Peningkatan mutu pendidikan mahasiswa dalam dunia perkuliahan berkaitan langsung dengan mahasiswa itu sendiri, dimana mahasiswa tersebut berperan sebagai peserta didik. Keberhasilan pendidikan dalam lingkungan perkuliahan dapat diketahui melalui ada tidaknya kemandirian dalam belajar mahasiswa. Kemandirian belajar mahasiswa dapat dipengaruhi oleh beberapa faktor dari mahasiswa itu sendiri khususnya kreativitas belajar dan motivasi belajar.

Belajar akan dapat memberikan suatu perubahan dalam diri seseorang, karena belajar bersifat untuk untuk mengetahui sampai seberapa jauh perubahan yang terjadi pada seorang mahasiswa yang mengikuti proses pembelajaran dalam perkuliahan. Seseorang yang melalui proses belajar pasti akan terwujud jiwa mandiri, karena dengan belajar dapat merubah sikap untuk dapat berdiri sendiri. Perubahan sikap seseorang dimana seseorang itu dapat berdiri sendiri tanpa bergantung pada orang lain dalam proses pembelajaran inilah yang disebut dengan kemandirian belajar.

Peserta didik yang dikatakan memiliki kemandirian dalam belajar apabila mampu berfikir kritis. Kemandirian belajar juga dapat meningkatkan intelegensia atau kecerdasan seseorang karena dengan kemandirian belajar peserta didik mampu berfikir kritis yang merupakan upaya pendalaman kesadaran serta kecerdasan membandingkan dari beberapa masalah yang sedang dan akan terjadi sehingga menghasilkan sebuah kesimpulan dan gagasan yang dapat memecahkan masalah tersebut. Setiap orang memiliki pola pikir yang berbeda. Akan tetapi, apabila setiap orang mampu berfikir secara kritis, masalah yang akan mereka hadapi tentu akan 


\section{$\pi$ (Phi)}

semakin sederhana dan mudah dicari solusinya.

Kemandirian belajar sangat perlu dimiliki oleh setiap peserta didik karena menurut teori konstruksivisme, dalam proses pembelajaran di sekolah, guru tidak bisa memberikan pengetahuan peserta didik begitu saja. Peserta didiklah yang harus membangun sendiri pengetahuannya. Misalnya dengan memberikan kesempatan seluas-luasnya kepada siswa untuk menemukan sendiri informasi dan mengaplikasikannya atau dengan pembelajaran yang mengupayakan pembelajaran peserta didik memiliki kesadaran untuk menggunakan strateginya sendiri dalam belajar.

Berdasarkan pengamatan peneliti sendiri yang terjadi pada mahasiswa sebagai peserta didik di lingkungan program studi pendidikan matematika FKIP Universitas Batanghari, masih banyak menemukan permasalahan permasalahan dalam proses pembelajaran diantaranya kurangnya disiplin dalam belajar, motivasi yang rendah dalam belajar yang menyebabkan mahasiswa tersebut malas untuk belajar. Salah satu masalah yang paling urgensi adalah masalah dalam kemampuan komunikasi matematis. Komunikasi matematis sangat diperlukan dalam memahami pembelajaran bidang matematika. Matematika merupakan ilmu universal yang mempunyai peranan penting dalam berbagai disiplin ilmu dan memajukan daya pikir serta ladasan seseorang untuk bernalar. Dalam belajar matematika, berhasil atau tidaknya seseorang ditandai dengan adanya kemampuan dalam menyelesaikan masalah yang dihadapinya. Masalah utama dalam pendidikan matematika adalah rendahnya kemampuan komunikasi matematisnya.

Kemampuan komunikasi adalah salah satu kemampuan dalam bermatematika yang mendasar yang harus dikuasai oleh peserta didik. Melalui komunikasi, terdapat proses penyampaian ide atau gagasan secara lisan ataupun tulisan sehingga menciptakan

pemahaman. Untuk memiliki kemampuan komunikasi matematis tersebut dibutuhkan kemandirian dalam belajar agar terlatih dan terbiasa mengungkapkan gagasan atau ideide baik tulisan maupun lisan. Apabila peserta didik memiliki kemampuan komunikasi matematis yang baik maka peserta didik juga menunjukan bahwa kalau mereka memilki kemandirian belajar dan intelegensia quotient yang baik pula. Karena orang yang memilki intelegensia yang baik dilihat dari kemampuan komunikasinya, dan tingkat intelegensia dapat dilatih melalui kemandirian belajar.

Adapun tujuan dari penelitian ini yakni pertama untuk mengetahui dan menganalisis pengaruh intelegensi quotient dan kemandirian belajar secara parsial terhadap kemampuan komunikasi matematis pada mahasiswa program studi pendidikan matematika. Apabila pengaruhnya telah diketahui satu persatu antar variabel independen maka pengajar akan lebih mudah mengetahui IQ mahasiswa dan cara belajar mandiri mereka sehingga pengajar dapat menerapkan berbagai macam strategi pembelajaran yang sesuai dengan tema mata kuliah sehingga mahasiswa dapat mengasah komunikasi matematisnya.

Tujuan yang kedua untuk mengetahui dan menganalisis pengaruh intelegensi quotient dan kemandirian belajar secara simultan terhadap kemampuan komunikasi matematis pada mahasiswa program studi pendidikan matematika. Apabila pengaruhnya telah diketahui secara bersama sama antar variabel independen maka pengajar akan lebih mudah untuk memberikan pengajaran pada mahasiswa dengan mengkombinasikan IQ mahasiswa dan cara belajar mandiri mereka sehingga pengajar dapat menerapkan berbagai macam strategi pembelajaran yang sesuai dengan tema mata kuliah sehingga mahasiswa dapat mengasah komunikasi matematisnya. 
$\pi$ (Phi)

\section{METODE PENELITIAN}

Penelititan ini, oleh penulis menggunakan rancangan penelitian dengan metode kuantitatif. Adapun yang dimaksud dengan metode penelitian kuantitatif adalah penelitian dalam bentuk angka-angka yang akan diolah untuk menguji suatu hipotesa

Adapun variabel dalam penelitian ini adalah 1) Variabel bebas atau Independent yakni intelegensi quotient (X1) dan kemandirian belajar (X2), dan 2) Variabel terikat atau dependent yakni kemampuan komunikasi matematika (Y). Populasi dari penelitian ini adalah mahasiswa program studi pendidikan matematika FKIP Universitas Batanghari dengan Jumlah keseluruhan mahasiswa yang ada program studi tersebut sebanyak 58 mahasiswa. Sehingga sampel penelitian ini adalah populasi itu sendiri. Menurut Sugiyono (2012) sampel adalah bagian dari jumlah dan karakteristik yang dimiliki oleh populasi tersebut. Penentuan sampel yang digunakan dalam penelitian ini adalah Populasi yang djadikan sebagai sampel karena Populasi kurang dari 100 orang. Selanjutnya dari sampel tersenut diambil beberpa orang secara random untuk dilakukan uji coba validitas dan reliabilitas. Setelah data hasilnya valid dan reliable baru dilakukan penyebaran data untuk penelitian dan dilakukan langkah teknik analisis data selanjutnya.

Teknik analisis data penelitian ini adalah regresi linier berganda, dimana untuk pengolajhan datanya menggunakan alat bantu program komputer SPSS versi 20 (Gozali, 2011). Langkah-langkah sebelum melakukan analisis regresi linier berganda terlebih dahulu data diolah dengan uji analissi deskriptif untuk mengetahui gambaran dari masing-masing variabel penelitian. Setelah melakukan analisis deskriptif, langkah selanjutnya melakukan uji analsisis statistik parametrik untuk mengetahui tingkat normalitas, liniearitas dan homogenitas data masing-masing variabel penelitian. Setelah itu dilakukan uji asumsi klasik untuk mengetahui autokolerasi, multikolinieritas, dan heterosedaksitas. Apabila syarat-syarat tersebut terpenuhi barulah bisa melakukan analisis regresi linier berganda dan akan dilanjutkan pada pengujian hipotesis dengan menggunakan uji F, uji t dan koefesien determinasi.

\section{HASIL DAN PEMBAHASAN}

\section{Hasil Uji Prasyarat Statistik Parametrik}

\section{1) Normalitas Data}

Uji normalitas di sini, peneliti menggunakan pendekatan kolmogorovSminov (KS) untuk mengetahui apakah data yang telah diperoleh selama penelitian berasal dari distribusi data yang normal ataukah tidak. Metode untuk menguji taraf kenormalan menggunakan bantuan SPSS versi 23 yang dapat dilihat pada tabel 1 berikut:

Tabel 1. Uji Normalitas

\begin{tabular}{|c|c|c|c|c|}
\hline \multicolumn{5}{|c|}{ One-Sample Kolmogorov-Smirnov Test } \\
\hline & & IQ & KB & KKM \\
\hline \multicolumn{2}{|l|}{$\mathrm{N}$} & 72 & 72 & 72 \\
\hline \multirow{2}{*}{$\begin{array}{l}\text { Normal } \\
\text { Parameters }^{\mathrm{a}, \mathrm{b}}\end{array}$} & Mean & 54,56 & 54,82 & 54,60 \\
\hline & $\begin{array}{l}\text { Std. } \\
\text { Deviation }\end{array}$ & 3,749 & 3,663 & 3,740 \\
\hline Most Extreme & Absolute & ,099 & 099 & ,096 \\
\hline \multirow{2}{*}{ Differences } & Positive & ,084 & ,097 & 074 \\
\hline & Negative &,- 099 &,- 099 &,- 096 \\
\hline \multirow{2}{*}{\multicolumn{2}{|c|}{$\begin{array}{l}\text { Test Statistic } \\
\text { Asymp. Sig. (2-tailed) }\end{array}$}} & 099 & 099 & 096 \\
\hline & &, $079^{\mathrm{c}}$ & $076^{\mathrm{c}}$ &, $095^{\mathrm{c}}$ \\
\hline \multicolumn{5}{|c|}{$\begin{array}{l}\text { a. Test distribution is Normal. } \\
\text { b. Calculated from data. } \\
\text { c. Lilliefors Significance Correction. }\end{array}$} \\
\hline
\end{tabular}

Dari tabel uji normalitas di atas bila dilihat dengan taraf nyata $5 \%$ atau taraf signifikansi 0,05, dapat disimpulkan bahwa data pada masing-masing variabel bebas maupun terikat berdistribusi normal. Untuk variabel intelegensi quotient (X1) memilki nilai Asymp. Sig sebesar 0,079, variabel kemandirian belajar (X2) sebesar 0,076, dan variabel kemampuan komunikasi matematika (Y) sebesar 0,095. Sehingga dapat disimpulkan bahwa data masingmasing variabel tersebut berdistribusi normal. Karena dari tabel tersebut diketahui bahwa nilai Asymp. Sig masing masing variabel $>0,05$. 


\section{$\pi$ (Phi)}

2) Hasil Uji Linieritas

Untuk menguji kelinieran data peneliti menggunakan SPSS 23. Apabila nilai signifikansi deviation from linearity $>$ 0,05 maka dikatakan bahwa data tersebut variabelnya memiliki hubungan yang linier. Dan apabila nilai signifikansi deviation from linearity < 0,05 maka dapat dikatakan bahwa data tersebut variabelnya memiliki hubungan yang tidak linier. Hasil uji linieritas dapat dilihat pada tabel 2 berikut ini:

Tabel 2 Uji Linieritas

\begin{tabular}{|c|c|c|c|c|c|c|}
\hline \multicolumn{7}{|c|}{ ANOVA Table KKM $*$ KB } \\
\hline & & $\begin{array}{l}\text { Sum of } \\
\text { Squares }\end{array}$ & $\mathrm{df}$ & $\begin{array}{c}\text { Mean } \\
\text { Square }\end{array}$ & $\mathrm{F}$ & Sig. \\
\hline \multirow[t]{3}{*}{$\begin{array}{l}\text { Between } \\
\text { Groups }\end{array}$} & $\begin{array}{l}\text { (Combine } \\
\text { d) }\end{array}$ & 140,103 & 11 & 12,737 & ,896 &, 550 \\
\hline & Linearity & 7,902 & 1 & 7,902 & ,556 & ,459 \\
\hline & $\begin{array}{l}\text { Deviation } \\
\text { from } \\
\text { Linearity }\end{array}$ & 132,201 & 10 & 13,220 & ,930 &, 513 \\
\hline \multicolumn{2}{|c|}{ Within Groups } & 853,217 & 46 & 14,220 & & \\
\hline \multicolumn{2}{|l|}{ Total } & 993,319 & 57 & & & \\
\hline
\end{tabular}

\begin{tabular}{|c|c|c|c|c|c|c|}
\hline \multicolumn{7}{|c|}{ ANOVA Table KKM $*$ IQ } \\
\hline & & $\begin{array}{l}\text { Sum of } \\
\text { Squares }\end{array}$ & $\mathrm{df}$ & $\begin{array}{l}\text { Mean } \\
\text { Square }\end{array}$ & $\mathrm{F}$ & Sig. \\
\hline \multirow[t]{3}{*}{$\begin{array}{l}\text { Between } \\
\text { Groups }\end{array}$} & $\begin{array}{l}\text { (Combine } \\
\text { d) }\end{array}$ & 295,967 & 13 & 22,767 & 1,894 & ,050 \\
\hline & Linearity & 45,946 & 1 & 45,946 & 3,821 & ,055 \\
\hline & $\begin{array}{l}\text { Deviation } \\
\text { from } \\
\text { Linearity }\end{array}$ & 250,021 & 12 & 20,835 & 1,733 & ,083 \\
\hline \multicolumn{2}{|c|}{ Within Groups } & 697,353 & 44 & 12,023 & & \\
\hline \multicolumn{2}{|l|}{ Total } & 993,319 & 57 & & & \\
\hline
\end{tabular}

Output hasil uji linieritas tersebut dilihat pada tabel uji anova, diketahui bahwa hubungan variabel intelegensi quotient (X1) dengan kemampuan komunikasi matematika (Y) memilki hubungan yang linier. Hal tersebut dikarenakan nilai signifikansi dari deviation from linearity sebesar 0,083 > taraf signifikansi 0,05. Selanjutnya hubungan variabel kemandirian belajar (X2) dengan kemampuan komunikasi matematika (Y) memilki hubungan yang linier, dilihat dari taraf signifikansi deviation from linearity sebesar 0,513 > taraf signifikansi 0,05. Sehingga dapat disimpulkan bahwa data tersebut variabelnya memiliki hubungan yang linier.

\section{3) Uji Homogenitas}

Uji homogenitas bertujuan untuk mengetahui apakah variasi beberapa data dari populasi memilki varians yang sama atau tidak. Berikut hasil dari pengujian homogenitas dapat dilihat pada table 3:

Tabel 3 Uji Homogenitas

\begin{tabular}{|c|c|c|c|}
\hline \multicolumn{4}{|c|}{ Test of Homogeneity of Variances } \\
\hline \multicolumn{4}{|l|}{ IQ*KKM } \\
\hline \multicolumn{4}{|l|}{ Levene } \\
\hline Statistic & df1 & df2 & Sig. \\
\hline 1,089 & 11 & 46 & ,386 \\
\hline \multicolumn{4}{|c|}{ Test of Homogeneity of Variances } \\
\hline \multicolumn{4}{|l|}{ KB*KKM } \\
\hline \multicolumn{4}{|l|}{ Levene } \\
\hline Statistic & df1 & df2 & Sig. \\
\hline 1,577 & 11 & 46 &, 540 \\
\hline
\end{tabular}

Dari tabel output di atas diketahui bahwa uji homogenitas yang dilihat dari sig levene statistic untuk masing masing hubungan variabel intelegensi quotient (X1) dengan kemampuan komunikasi matematika (Y) sebesar 0,386 > 0,05, sehingga bisa dikatakan data tersebut adalah homogen. Selanjutnya untuk variabel kemandirian belajar (X2) dengan kemampuan komunikasi matematika (Y) sebesar 0,540 , sehingga dapat pula dikatakan data tersebut adalah homogen.

\section{Hasil Uji Asumsi Klasik \\ 1) Uji Multikolinearitas}

Uji multikolinearitas bertujuan untuk menguji apakah model regresi ditemukan adanya korelasi antar variabel bebas. Model regresi yang baik seharusnya tidak terjadi korelasi diantara variabel bebas. Untuk mengetahui adanya multikolinearitas dalam model regresi dapat dilihat dari nilai Variance Inflation Faktor (VIF). Hasil perhitungan data untuk uji multikoliniearitas dapat dilihat pada tabel berikut: 
Tabel 4 Uji Multikolinearitas

\begin{tabular}{ccc}
\hline \multicolumn{3}{c}{ Collinearity Statistics } \\
\hline Tolerance & \multicolumn{2}{c}{ VIF } \\
\hline, 823 & & 1,215 \\
, 823 & 1,215 \\
\hline
\end{tabular}

Dari hasil output yang terlihat pada table di atas menunjukkan bahwa baik intelegensi quotient dan kemandirian belajar memiliki nilai tolerance kurang dari 1 dan VIF memiliki nilai kurang dari 10 maka dapat dikatakan data tidak mengalami multikolinieritas.

\section{2) Uji Heterosdeksitas}

Uji heterosdekastisitas bertujuan untuk menguji apakah dalam model regresi terjadi ketidaksamaan varian dari residual atau pengamatan yang lain. Beberapa cara untuk mengetahui ada atau tidaknya heteroskedastisitas dalam model regresi, namun pada penelitian ini menggunakan uji Glejser. Berikut hasil dari pengujian heterosdekasitas dapat dilihat pada tabel di bawah ini:

\begin{tabular}{|c|c|c|c|c|c|c|}
\hline \multicolumn{7}{|c|}{ Tabel 5 Uji Heterosdeksitas Coefficients ${ }^{\mathrm{a}}$} \\
\hline \multirow[b]{2}{*}{ Model } & & \multicolumn{2}{|c|}{$\begin{array}{l}\text { Unstandardize } \\
\text { d Coefficients }\end{array}$} & $\begin{array}{c}\text { Stand } \\
\text { ardize } \\
\text { d } \\
\text { Coeff } \\
\text { icient } \\
\text { s } \\
\end{array}$ & \multirow[b]{2}{*}{$\mathrm{t}$} & \multirow[b]{2}{*}{ Sig. } \\
\hline & & $\mathrm{B}$ & $\begin{array}{l}\text { Std. } \\
\text { Error }\end{array}$ & Beta & & \\
\hline 1 & (Constant) & 1,511 & 4,052 & & 373 & ,710 \\
\hline & IQ & 018 & ,068 & 036 & ,269 & ,788 \\
\hline & KB &, 010 & 070 & 020 & 151 & ,880 \\
\hline
\end{tabular}

Dari Tabel 4.6 menunjukkan bahwa pengujian ini menggunakan metode uji Glejser yang nilainya dilihat dari $\mathrm{t}$ sig. Pada variabel intelegensi quotient (x1) dan kemandirian belajar (X2) memiliki nilai sig lebih besar daripada 0,05 yakni masingmasing nilai Sig sebesar 0,788 dan 0,880, maka dapat dikatakan data tidak terjadi heteroskedastisitas.

\section{Analisis Regresi Berganda}

Analisis ini digunakan untuk mengukur kekuatan hubungan antara variabel bebas yaitu intelegensi quotient (X1) dan kemandirian belajar (X2) dengan variabel terikat kemampuan komunikasi matematika (Y), serta untuk menunjukkan arah hubungan variabel-variabel tersebut. Analisis ini akan membentuk sebuah persamaan yang dapat dijelaskan hasilnya pada tabel di bawah ini:

Tabel 6 Analisis Regresi Coefficients ${ }^{\mathrm{a}}$

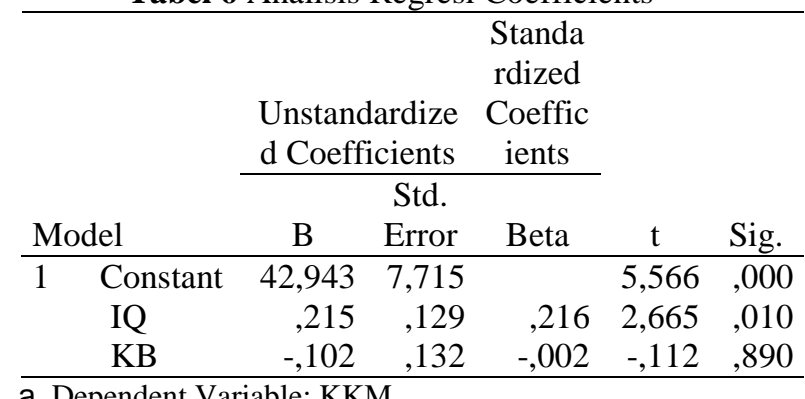

Berdasarkan tabel 6 diatas menunjukkan koefisien ß merupakan bentuk sebuah persamaan regresi yang dapat dihasilkan sebagai berikut: $\mathrm{Y}=42,943+$ 0,215 X1 - 0,102 X2 + e. Dari persamaan diatas maka dapat dijadikan acuan untuk diintepretasikan sebagai berikut:

1. Koefisien Konstanta bernilai positif artinya bahwa ketika kemampuan komunikasi matematika tidak memperhatikan intelegensi quotient dan kemandirian belajar akibat yang ditimbulkan mahasiswa akan tetap memiliki kemampuan komunikasi matematika.

2. Koefisien intelegensi quotient bernilai positif artinya setiap kenaikan intelegensi quotient yang dimiliki mahasiswa meningkat, akan disertai dengan peningkatan kemampuan komunikasi matematika juga. Sedangkan setiap penurunan intelegensi quotient yang dimiliki mahasiswa menurun, akan disertai penurunan kemampuan komunikasi matematika.

3. Koefisien kemandirian bernilai negatif artinya setiap usaha yang dilakukan 


\section{$\pi$ (Phi)}

mahasiswa untuk belajar mandiri menurun, akan disertai dengan penurunan kemampuan komunikasi matematika jug dan demikian pula sebaliknya

\section{4) Pengaruh Intelegensi Quotient Terhadap Kemampuan Komunikasi Matematika Secara Parsial}

Hasil dari uji t dapat dilihat pada tabel 6 diperoleh nilai t hitung untuk variabel intelegensi quotient (X1) sebesar 2,665 dengan taraf nilai Sig $=0,010$. Pengujian hipotesis yang diajukan diterima atau ditolak yaitu dengan melihat nilai $\mathrm{t}$ dan taraf nilai signifikansi. Adapun hipotesis yang diajukan adalah sebagai berikut:

$\mathrm{H}_{0}$ : tidak ada pengaruh Intelligence Quotient (IQ) terhadap kemampuan komunikasi matematika

$\mathrm{H}_{1} \quad$ : ada pengaruh Intelligence Quotient (IQ) terhadap kemampuan komunikasi matematika

Ketentuan penerimaan atau penolakan terjadi jika nilai $\mathrm{t}$ hitung $>\mathrm{t}$ tabel dan taraf nilai Sig $<0,05$, maka $\mathrm{H}_{0}$ ditolak. Sedangkan jika nilai t hitung $<\mathrm{t}$ tabel dan taraf nilai Sig $>0,05$, maka $\mathrm{H}_{0}$ diterima. Sebelum melihat nilai $\mathrm{t}$ tabel, maka terlebih dahulu harus menentukan derajat kebebasan (dk). Pada keseluruhan sampel yang diteliti (N) dengan rumus $\mathrm{dk}=\mathrm{n}-2$. Dalam penelitian ini, jumlah prediktor ada 2 (X1 dan X2) dan jumlah sampel yang digunakan adalah 58 mahasiswa maka dk $=58-2=56$ pada taraf signifikansi 5\%. Maka ditemukan nilai $\mathrm{t}$ tabel $=1,671$. Karena nilai $\mathrm{t}$ hitung variabel intelegensi quotient sebesar 2,665 > $\mathrm{t}$ tabel $=1,671$ dan taraf nilai Sig $=0,010<$ 0,05, sehingga dapat disimpulkan bahwa $\mathrm{H}_{0}$ ditolak, artinya ada pengaruh Intelligence Quotient (IQ) terhadap kemampuan komunikasi matematika. Oleh karena itu kemampuan komunikasi matematika mahasiswa program studi pendidikan matematika dipengaruhi oleh Intelligence Quotient (IQ) secara parsial. Maksudnya jika IQ mahasiswa tinggi maka kemampuan komunikasi matematika mahasiswa juga tinggi, dan sebaliknya jika IQ mahasiswa rendah maka kemampuan komunikasi matematika mahasiswa juga rendah.

Selanjutnya variabel kemandirian belajar (X2) diperoleh hasil uji t yang dapat dilihat pada tabel 4.8 sebesar -0,112 dengan taraf nilai Sig $=0,890$. Pengujian hipotesis yang diajukan diterima atau ditolak yaitu dengan melihat nilai $\mathrm{t}$ dan taraf nilai signifikansi. Adapun hipotesis yang diajukan adalah sebagai berikut:

$\mathrm{H}_{0}$ : tidak ada pengaruh Kemandirian Belajar (KB) terhadap kemampuan komunikasi matematika

$\mathrm{H}_{1}$ : ada pengaruh Kemandirian Belajar (KB) terhadap kemampuan komunikasi matematika

Ketentuan penerimaan atau penolakan terjadi jika nilai t hitung $>\mathrm{t}$ tabel dan taraf nilai Sig $<0,05$, maka H0 ditolak. Sedangkan jika nilai t hitung $<\mathrm{t}$ tabel dan taraf nilai Sig $>0,05$, maka H0 diterima. Sebelum melihat nilai t tabel, maka terlebih dahulu harus menentukan derajat kebebasan (dk). Pada keseluruhan sampel yang diteliti (N) dengan rumus $\mathrm{dk}=\mathrm{n}-2$. Dalam penelitian ini, jumlah prediktor ada 2 (X1 dan X2) dan jumlah sampel yang digunakan adalah 58 mahasiswa maka dk $=58-2=56$ pada taraf signifikansi 5\%. Maka ditemukan nilai t tabel $=1,671$. Karena nilai t hitung variabel kemandirian belajar sebesar $-0,112$ $<\mathrm{t}$ tabel $=1,671$ dan taraf nilai Sig $=0,890$ $>0,05$, sehingga dapat disimpulkan bahwa $\mathrm{H}_{0}$ diterima, artinya tidak ada pengaruh kemandirian belajar (KB) terhadap kemampuan komunikasi matematika. Oleh karena itu kemampuan komunikasi matematika mahasiswa program studi pendidikan matematika tidak dipengaruhi oleh Kemandirian Belajar (KB) secara parsial. Maksudnya jika kemandirian belajar mahasiswa rendah maka kemampuan komunikasi matematika mahasiswa tidak musti rendah karena ada variabel lain yang mempengaruhi selain kemandirian belajar.

Begitu juga apa yang terjadi dilapangan, di kampus mahasiswa yang 


\section{$\pi$ (Phi)}

memiliki IQ tinggi akan memiliki kemampuan komuniasi matematika juga tinggi. Inteligensi dianggap sebagai suatu norma yang sangat menentukan perkembangan kemampuan dan pencapaian yang optimal hasil belajar peserta didik. Karena inteligensi merupakan bekal potensial yang akan memudahkan dalam belajar dan pada gilirannya akan menghasilkan prestasi belajar yang optimal. Sedangkan kemandirian belajar yang dimilki mahasiswa program studi pendidikan matematika kurang begitu diterapkan, karena mahasiswa selalu mengandalkan dosen untuk terlebih dahulu menjelaskan apa yang tersaji pada materi perkuliahan, mereka belum ada inisiatif untuk mempelajarinya terlebih dahulu dan menanyakan kepada dosen apabila menemukan kendala permasalahan dalam pembelajaran.

Hasil penelitian secara parsial tentang kemandirian belajar terhadap kemampuan komunikasi matematika tersebut bertolak belakang dengan apa yang dikemukakan oleh Uno (2011) yaitu metode belajar dengan kecepatan sendiri, tanggung jawab sendiri, dan belajar yang berhasil. Jadi, berhasil tidaknya dalam belajar semuanya ditentukan oleh pribadi tersebut. Dalam penelitian ini menerangkan bahwa kemandirian belajar tidaklah cukup untuk meningkatkan kemampuan komunikasi matematika diperlukan unsur lain seperti bantuan dari penjelasan dosen.

5) Pengaruh Intelegensi Quotient dan Kemandirian Belajar Terhadap Kemampuan Komunikasi Matematika Secara Simultan

Berdasarkan perhitungan ANOVA untuk melihat uji F berikut ini:

\begin{tabular}{|c|c|c|c|c|c|c|}
\hline \multicolumn{6}{|c|}{ Tabel 7} & $\begin{array}{l}\text { matematika dipengaruhi oleh } \\
\text { Outient (IO) dan kemandirian }\end{array}$ \\
\hline \multirow[b]{2}{*}{ Model } & & Sum & & Mea & & \\
\hline & & Squares & Df & Square & $\mathrm{F}$ & \\
\hline \multirow[t]{4}{*}{1} & Regre & 45,948 & 2 & 22,974 & 3,673 & 0 \\
\hline & Residual & 947,372 & 55 & 13,730 & & va \\
\hline & Total & 993,319 & 57 & & & kasi matematika $\mathrm{n}$ \\
\hline & dent Vari & KKM & & & & 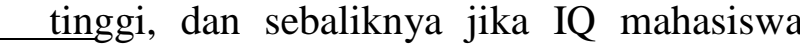 \\
\hline
\end{tabular}

Pengaruh Intelegensi Quotient Dan Kemandirian Belajar Terhadap Kemampuan Komunikasi Matematis Pada Mahasiswa Program Studi Pendidikan Matematika

b. Predictors: (Constant), KB, IQ

Diperoleh nilai $\mathrm{F}$ hitung $=3,673$ dengan taraf nilai Sig $=0,015$. Untuk menguji hipotesis yang diajukan diterima atau ditolak yaitu dengan melihat nilai $\mathrm{F}$ dan taraf nilai signifikansi. Adapun hipotesis yang diajukan adalah sebagai berikut:

$\mathrm{H}_{0}$ : tidak ada pengaruh Intelligence Quotient (IQ) dan Kemandirian Belajar (KB) terhadap kemampuan komunikasi matematika

$\mathrm{H}_{1} \quad$ : ada pengaruh Intelligence Quotient (IQ) dan Kemandirian Belajar (KB) terhadap kemampuan komunikasi matematika

Pengambilan keputusan hipotesis tersebut didasarkan dengan ketentuan penerimaan atau penolakan terjadi apabila Jika nilai $\mathrm{F}$ hitung $>\mathrm{F}$ tabel dan taraf nilai Sig < 0,05, maka H0 ditolak. Jika nilai Fhitung $<$ F tabel dan taraf nilai Sig $>0,05$, maka H0 diterima. Sebelum melihat nilai Ftabel, maka terlebih dahulu harus menentukan derajat kebebasan pembilang (df) dan derajat kebebasan penyebut (db). Pada keseluruhan sampel yang diteliti (N) dengan rumus $\mathrm{df}=\mathrm{m}$ (jumlah prediktor) dan $\mathrm{db}=\mathrm{N}-\mathrm{m}-1$. Dalam penelitian ini, jumlah prediktor ada 2 (X1 dan X2) dan jumlah sampel yang digunakan adalah 58 mahasiswa, maka $\mathrm{df}=2$ dan $\mathrm{db}=58-2-1$ $=55$ pada taraf signifikansi 5\%. Maka ditemukan nilai $\mathrm{F}$ tabel $=3,16$. Karena nilai Fhitung $=3,673>\mathrm{F}$ tabel $=3,16$ dan taraf nilai Sig $=0,015<0,05$, sehingga dapat disimpulkan bahwa H0 ditolak, artinya ada pengaruh Intelligence Quotient (IQ) dan Kemandirian Belajar (KB) terhadap kemampuan komunikasi matematika mahasiswa pendidikan matematika. Oleh karena itu kemampuan komunikasi matematika dipengaruhi oleh Intelligence Quotient (IQ) dan kemandirian belajar (KB) masiswa secara 15 aksudnya jika IQ mahasiswa tinggi dan komunikasi matematika mahasiswa juga 


\section{$\pi$ (Phi)}

rendah dan KB mahasiswa rendah maka kemampuan komunikasi matematika mahasiswa juga rendah. Begitu juga apa yang terjadi dilapangan, di kampus mahasiswa yang memiliki Intelligence Quotient tinggi dan Kemandirian Belajar tinggi pula kemampuan komunikasi matematika juga tinggi. Sehingga mahasiswa yang memilki Intelligence Quotient dan Kemandirian Belajar tinggi secara tidak langsung akan meningkatkan kemampuan komunikasi matematikanya sendiri.

Kemandirian belajar yang tinggi sangat dibutuhkan di dalam proses pembelajaran. Sesuai dengan pendapat Mujiman (2011) dimana belajar mandiri merupakan kegiatan belajar aktif, yang didorong oleh motif untuk menguasai sesuatu kompetensi, dan dibangun dengan bekal pengetahuan atau kompetensi yag telah dimiliki. Dalam penetepan kompetensi sebagai tujuan belajar dan cara pencapaiannya baik penetapan waktu belajar, tempat belajar, irama belajar, tempo belajar, cara belajar, sumber belajar, maupun evaluasi hasil belajar dilakukan sendiri. Mahasiswa yang memiliki tingkat kemandirian yang tinggi akan mampu mengambil keputusan yang positif untuk mengatasi masalah yang dihadapinya di dalam kampus maupun di luar kampus, mahasiswa akan memiliki rasa kepercayaan diri di dalam menyelesaikan atau menjawab tugas-tugas mata kuliah yang diberikan oleh dosen.

6) Besar Pengaruh Intelegensi Quotient dan Kemandirian Belajar Terhadap Kemampuan Komunikasi Matematika

Berdasarkan Tabel 8 Model

Summary pada uji koefesien determinasi $\left(R^{2}\right)$ dapat dilihat sebagai berikut:

Tabel 8 Uji Koefesien Determinasi

\begin{tabular}{|c|c|c|c|}
\hline \multicolumn{4}{|c|}{ Model Summaryb } \\
\hline & & Adjusted & Std. Error of the \\
\hline Model & Square & R Square & Estimate \\
\hline 1 &, $656^{\mathrm{a}}$ & ,282 & 3,705 \\
\hline $\begin{array}{l}\text { a. Predi } \\
\text { b. Depe }\end{array}$ & $\begin{array}{l}\text { ors: (Constant), } \\
\text { dent Variable: K }\end{array}$ & $\begin{array}{l}\mathrm{KB}, \mathrm{IQ} \\
\mathrm{KM}\end{array}$ & \\
\hline
\end{tabular}

Dijelaskan bahwa variabel Intelligence Quotient (IQ) dan Kemandirian Belajar (BK) secara bersama-sama mempengaruhi variabel kemampuan komunikasi matematika mahasiswa pendidikan matematika. Pada tabel tersebut diperoleh nilai Adjusted $\mathrm{R}$ Square adalah 0,430 yang artinya 43\% kemampuan komunikasi matematika dipengaruhi oleh Intelligence Quotient (IQ) dan Kemandirian Belajar (KB) secara bersama-sama. Menurut Sugiyono (2013), untuk melihat kriteria interpretasi pengaruh Intelligence Quotient (IQ) dan Kemandirian Belajar terhadap Kemampuan komunikasi matematika dapat dilihat berdasarkan kriteria berikut:

Interval Interpretasi 0\% - 39\% Rendah Interval Interpretasi 40\% - 59\% Sedang Interval Interpretasi 60\% - 79\% Cukup Interval Interpretasi 80\% - 100\% Tinggi

Berdasarkan kriteria tersebut, terlihat bahwa $43 \%$ terletak pada interval 40\% - 59\%, maka interpretasinya adalah sedang. Sehingga pengaruh Intelligence Quotient (IQ) dan Kemandirian Belajar (KB) terhadap kemampuan komunikasi matematika yaitu $43 \%$ termasuk kedalam kriteria sedang. Artinya mahasiswa pendidikan matematika memilki kemampuan komunikasi matematika "sedang” yang disebabkan oleh Intelligence Quotient (IQ) dan Kemandirian Belajar (KB)..

\section{SIMPULAN DAN SARAN}

Berdasarkan hasil analisis terhadap data yang telah dikumpulkan, maka dapat disimpulkan sebagai berikut:

1. Secara parsial telah diperoleh perhitungan dan pembahasan bahwa variabel intelegensi quotient (X1) berpengaruh positif secara signifikan terhadap kemampuan komunikasi matematika (Y) sehingga $\mathrm{H} 0$ ditolak dan $\mathrm{H} 1$ diterima. Sedangkan untuk variabel kemandirian belajar (X2) diperoleh perhitungan dan pembahasan bahwa tidak ada pengaruh yang signifikan terhadap kemampuan 


\section{$\pi$ (Phi)}

komunikasi matematika (Y), sehingga H0 diterima dan $\mathrm{H} 1$ ditolak

2. Secara simultan intelegensi quotient (X1) dan kemandirian belajar (X2), beperngaruh signifikan terhadap kemampuan komunikasi matematika (Y), sehingga $\mathrm{H} 0$ ditolak dan $\mathrm{H} 1$ diterima

3. Kemampuan variabel intelegensi quotient (X1) dan kemandirian belajar (X2) menerangkan variasi variabel kemampuan komunikasi matematika (Y) sebesar 43\% dan sisanya diperngaruh variabel independen lainnya sebesar 57\%.

\section{DAFTAR PUSTAKA}

Bungin, Burhan. (2007). Sosiologi Komunikasi. Jakarta: Kencana, 57.

Clark, K. K. (2005). Strategies for Building Mathematical Communication in the Middle School Classroom: Modeled in Professional Development, Implemented in the Classroom. CIME (Current Issues in Middle Level Education), Vol. 11, No. 2, 1-12

Ghozali, Imam. (2011). "Aplikasi Analisis Multivariate Dengan Program SPSS". Semarang: Badan Penerbit Universitas Diponegoro.

Kosko, K.W. and Wilskins, J.L.M. (2010). Mathematical Communication and Its Relation to the Frequency of Manipulative Use. International Electronic Journal of Mathematics Education (IEJME), Vol. 5, No. 2, 79-90.

Mujiman, Haris. (2011). Manajemen Pelatihan Berbasis Belajar Mandiri. Yogyakarta: Pustaka Pelajar.

NCTM. (2010). Principles and Standards for School Mathematics. http://www.nctm.org/StandardsandPositions/Principles-andStandards/ Principles,-Standards,-andExpectations/. Diakses pada 28 Oktober 2016.

Prayuda, Reza, Thomas Yosep, dan Basri M. (2014). Pengaruh Kemandirian

Belajar Terhadap Hasil Belajar Siswa Pada Mata Pelajaran Ekonomi di SMA. Skripsi: Universitas Tanjung Pura.

Sugiyono. (2013). Metode Penelitian Kuantitatif, Kualitatif, dan Kombinasi (Mixed methods). Bandung: Alfabeta, $10-11$

Syah, Muhibbin. (2013). Psikologi Belajar. Jakarta: Raja Grafindo Persada.

Uno, H. (2011). Teori Motivasi dan Pengukurannya. Jakarta: PT Bumi AksaraBandung PT Remaja Rosdaka Karya 